\title{
Selective synthesis of thiodiglycol dicarboxylic acid esters via $p$-TsOH/C-catalysed direct esterification
}

\author{
DAHONG JIANG and MIN HUANG* \\ Department of Chemistry and Life Science, Guangdong University of Petrochemical Technology, \\ Maoming 525000, China \\ e-mail: min_huang@163.com
}

MS received 10 November 2011; accepted 10 April 2012

\begin{abstract}
The esterification of thiodiglycol and long alkyl-chain carboxylic acids is reported. Reaction of thiodiglycol with carboxylic acid via $p$-TsOH/C-catalysed direct esterification afforded thiodiglycol dicarboxylic acid esters in good yields and chemoselectivity. The use of immobilized $p$-TsOH on activated carbon as catalyst is crucial for the transformation.
\end{abstract}

Keywords. Thiodiglycol dicarboxylic acid esters; catalytic esterification; $p$-Ts $\mathrm{TH}$ on activated carbon; antioxidant.

\section{Introduction}

The long alkyl-chain esters of thiodiglycol are widely employed in various commercial applications. For instance, they have been proposed as lubricating agents, softening agents, emulsifiers, dispersing agents, and wetting agents. ${ }^{1}$ Recently, their analogues are reported to be used as antioxidant for polymers. ${ }^{2}$ Thus, their synthesis has attracted interest from synthetic chemists. ${ }^{3}$ Due to the simple procedure and readily available precursors, acid-catalysed direct esterification has been well-established as a means of formation of esters from alcohols and acids. ${ }^{4}$ However, the method employing acid-catalysed direct esterification of carboxylic acids with thiodiglycol to form the corresponding esters is quite limited. It is well-known that dithiane, linear polymeric ethers and oxathiane are formed under the conditions, ${ }^{5}$ making the method less adaptable to the synthesis of thiodiglycol dicarboxylic acid esters.

Solid-supported acids are recognized as environmentally benign catalysts for esterification, and they also afford great convenience in terms of preparation and purification of esters. ${ }^{6}$ Here, we report a chemo-selective synthesis of thiodiglycol long alkylchain dicarboxylic acid esters via $p$-TsOH/C-catalysed esterification of carboxylic acids with thiodiglycol.

*For correspondence

\section{Experimental}

\subsection{Preparation of $p-T s O H / C$}

The active carbon $(25 \mathrm{~g})$ was immersed in $100 \mathrm{~mL}$ of $p$-TsOH in water $(25 \%)$ for $30 \mathrm{~h}$, and then filtrated. The solid was dried in oven at $110^{\circ} \mathrm{C}$ for $5 \mathrm{~h}$ and used without any further manipulation. The loading of $p$-TsOH on carbon was determined as $0.203 \mathrm{~g}$ per gram of active carbon by comparing the weights of active carbon and the catalyst.

\subsection{General procedure}

Thiodiglycol 1 (1.5 equiv), carboxylic acid 2 (1.0 equiv) and $p$-TsOH/C (4 w\% of acid) were mixed with $20 \mathrm{~mL}$ of xylene. The mixture was refluxed for $2 \mathrm{~h}$ until no water was carried out by xylene. The reaction mixture was cooled to room temperature and filtered. Precipitate appeared by the addition of ethanol to the filtrate. The crude product was filtered and further purified by recrystallization in ethanol which afforded $\mathbf{3}$.

\subsection{Characterization of products}

2.3a 3a: White solid. m.p. $48-50^{\circ} \mathrm{C}{ }^{1} \mathrm{H}$ NMR $\left(300 \mathrm{MHz}, \mathrm{CDCl}_{3}\right) \delta 4.21(2 \mathrm{H}, \mathrm{m}), 2.29(2 \mathrm{H}, \mathrm{t}, J=$ $5.7 \mathrm{~Hz}), 1.59(2 \mathrm{H}, \mathrm{t}, J=5.4 \mathrm{~Hz}), 1.23-1.26(16 \mathrm{H}, \mathrm{m})$, $0.85(3 \mathrm{H}, \mathrm{r}, J=5.1 \mathrm{~Hz}) ;{ }^{13} \mathrm{C}$ NMR $\left(75 \mathrm{MHz}, \mathrm{CDCl}_{3}\right)$ $\delta 173.8,63.4,32.0,30.7,29.7,29.6,29.5,29.4,29.3$, 25.0, 24.9, 22.8, 14.3; MS-EI $(m / z) 86,69,57,43$. 
2.3b 3b: White solid. 58-60 ${ }^{\circ} \mathrm{C}^{1} \mathrm{H}$ NMR $(300 \mathrm{MHz}$, $\left.\mathrm{CDCl}_{3}\right) \delta 4.21(2 \mathrm{H}, \mathrm{m}), 2.29(2 \mathrm{H}, \mathrm{t}, J=5.7 \mathrm{~Hz}), 1.59$ $(2 \mathrm{H}, \mathrm{t}, J=5.1 \mathrm{~Hz}), 1.23-1.26(20 \mathrm{H}, \mathrm{m}), 0.86(3 \mathrm{H}$, $\mathrm{r}, J=5.1 \mathrm{~Hz}) ;{ }^{13} \mathrm{C} \mathrm{NMR}\left(75 \mathrm{MHz}, \mathrm{CDCl}_{3}\right) \delta 173.9$, 63.5, 30.0, 29.9, 29.8, 29.7, 29.6, 29.5, 29.4, 25.2, 23.0, 14.4; MS-EI $(m / z) 86,71,57,43,41$.

2.3c 3c: White solid. $58-61{ }^{\circ} \mathrm{C}^{1} \mathrm{H}$ NMR $(300 \mathrm{MHz}$, $\left.\mathrm{CDCl}_{3}\right) \delta 4.20(2 \mathrm{H}, \mathrm{m}), 2.29(2 \mathrm{H}, \mathrm{t}, J=5.7 \mathrm{~Hz}), 1.59$ $(2 \mathrm{H}, \mathrm{t}, J=5.1 \mathrm{~Hz}), 1.23-1.26(24 \mathrm{H}, \mathrm{m}), 0.86(3 \mathrm{H}, \mathrm{r}$, $J=5.0 \mathrm{~Hz}) ;{ }^{13} \mathrm{C} \mathrm{NMR}\left(75 \mathrm{MHz}, \mathrm{CDCl}_{3}\right) \delta 174.0,63.6$, 30.0, 29.9, 29.9, 29.8, 29.6, 29.5, 29.4, 25.2, 23.0, 14.4; MS-EI $(m / z)$ 104, 86, 71, 57, 44, 41.

2.3d 3d: White solid. 57-60 ${ }^{\circ} \mathrm{C}^{1} \mathrm{H}$ NMR $(300 \mathrm{MHz}$, $\left.\mathrm{CDCl}_{3}\right) \delta 4.20(2 \mathrm{H}, \mathrm{m}), 2.29(2 \mathrm{H}, \mathrm{t}, J=5.7 \mathrm{~Hz}), 1.59$ $(2 \mathrm{H}, \mathrm{t}, J=5.4 \mathrm{~Hz}), 1.23-1.26(28 \mathrm{H}, \mathrm{m}), 0.86(3 \mathrm{H}, \mathrm{r}$, $J=5.1 \mathrm{~Hz}) ;{ }^{13} \mathrm{C} \mathrm{NMR}\left(75 \mathrm{MHz}, \mathrm{CDCl}_{3}\right) \delta 174.0,63.5$, 32.1, 31.7, 30.9, 29.9, 29.7, 29.5, 29.3, 25.1, 24.9, 22.9, 14.3; MS-EI $(m / z)$ 104, 86, 71, 57, 43.

\section{Results and discussions}

Generally, direct esterification needs either removal of water generated in the reaction or large excess amounts of one of the reactants to shift the equilibrium between reactants and products. ${ }^{7}$ In our preliminary studies on acid-catalysed direct esterfication of long alkyl-chain carboxylic acids with thiodiglycol, we have first examined the reaction of excess amount of thiodiglycol $\mathbf{1}$ with lauric acid 2a using xylene to remove water azeotropically. Some results from that study are summarized in table 1. Although thiodiglycol lauric acid ester 3a was obtained in moderate yield using condensed sulphuric acid as catalyst (entry 1, table 1), large amount of by-product which was determined as 1,4oxathiane 4 was observed. The compound 4 was considered the product of intramolecular condensation of thiodiglycol (scheme 1). We felt that the acid catalyst played an important role in terms of chemo-selectivity in this transformation. An attempted survey of catalysts was conducted. Phosphoric acid was proved to be less efficient (entry 2, table 1) and both $\mathrm{Ti}(\mathrm{O} n-\mathrm{Bu})_{4}$ and $\mathrm{SnCl}_{4}$ provided no detectable amounts of the desired product (entry 3 and 4, table 1). Fortunately, $p-\mathrm{TsOH}$ was found to be an efficient catalyst for the esterification (entry 5, table 1). We were pleased to find that this transformation provided $3 \mathbf{a}$ in $85 \%$ yield (entry 6 , table 1) and the amount of $\mathbf{4}$ decreased dramatically
Table 1. Catalyst effects on esterification of thiodiglycol with lauric acid. ${ }^{\mathrm{a}}$

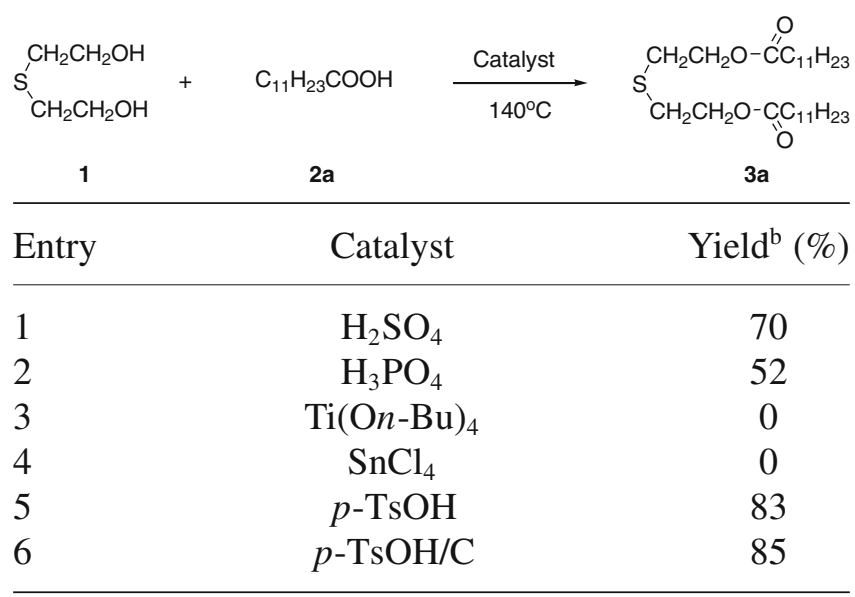

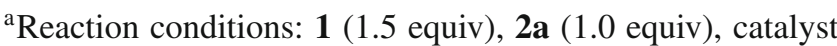
( $2 \mathrm{w} \%$ of carboxylic acid), xylene $(20 \mathrm{~mL}), 140^{\circ} \mathrm{C}, 2 \mathrm{~h}$. ${ }^{\mathrm{b}}$ Isolated yield

when active carbon-supported $p$-TsOH was employed as catalyst. To optimize the reaction conditions, we judiciously screened the azeotropical agents, catalyst loading and with results summarized in table 2. Xylene was proved to be clearly superior to other azeotropical agents, as hexane and toluene gave the product in lower yields. Balancing the yield and the cost, $4 \mathrm{w} \%$ of catalyst loading was selected for the sequent studies. An attempt to decrease the ratio of thiodiglycol to lauric acid to $1: 1$ gave much lower yield.

With the optimized reaction conditions in hand, we applied this methodology for the preparation of some other long alkyl-chain esters of thiodiglycol (table 3). The conversion of carboxylic acids containing 12 to 18 carbons to the corresponding thiodiglycol esters is performed smoothly under the reaction conditions. Neither thiodiglycol monocarboxylic acid esters nor its polymeric ethers were detected. Though the formation of 1,4-oxathiane can not be eliminated, it has no effect on the yields of esters, suggesting that the esterification might be much faster than the intramolecular condensation. This method did not necessitate special use of the technique of separation of catalyst. After completion of the reactions, the catalyst was separated through a simple filtration and could be reused several times without significant decrease in catalytic activity.

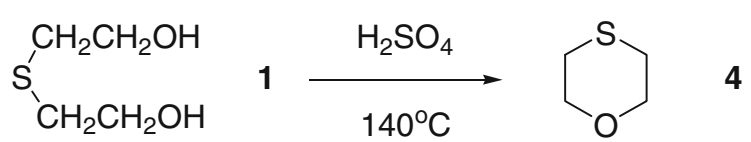

Scheme 1. Formation of 1,4-oxathiane. 
Table 2. Reaction conditions optimization.

\begin{tabular}{lcccc}
\hline Entry & $\begin{array}{c}\text { Azeotropical } \\
\text { agent }\end{array}$ & $\begin{array}{c}\text { Catalyst loading } \\
\text { (w\% of acid) }\end{array}$ & $\begin{array}{c}\text { Ratio } \\
\text { (thiodiglycol to acid) }\end{array}$ & Yield $^{\mathrm{a}}$ (\%) \\
\hline 1 & xylene & 2 & $1.5: 1$ & 85 \\
2 & hexane & 2 & $1.5: 1$ & 55 \\
3 & toluene & 2 & $1.5: 1$ & 68 \\
4 & xylene & 1 & $1.5: 1$ & 78 \\
5 & xylene & 4 & $1.5: 1$ & 92 \\
6 & xylene & 6 & $1.5: 1$ & 94 \\
7 & xylene & 8 & $1.5: 1$ & 93 \\
8 & xylene & 4 & $1: 1$ & 71 \\
\hline
\end{tabular}

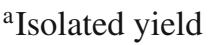

Table 3. $p$-TsOH/C-catalysed esterification of thioglycol with long chain carboxylic acid. $^{\mathrm{a}}$

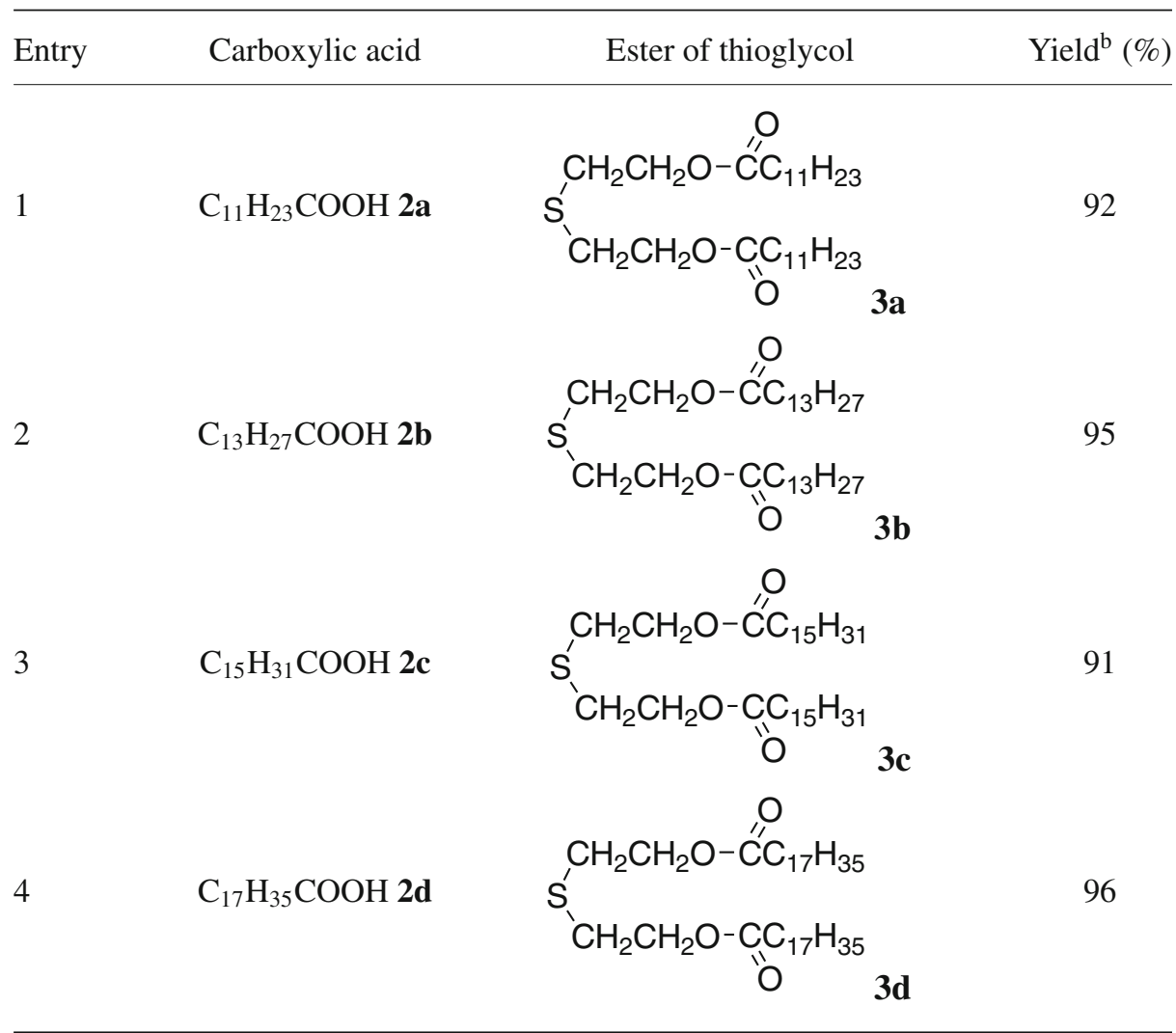

a Reaction conditions: 1 (1.5 equiv), 2 (1.0 equiv), catalyst ( $4 \mathrm{w} \%$ of acid), xylene $(20 \mathrm{~mL}), 140^{\circ} \mathrm{C}, 2$ h. ${ }^{\mathrm{b}}$ Isolated yield

\section{Conclusions}

In conclusion, we have developed a chemoselective heterogeneous $p$-TsOH/C-catalysed route to long alkylchain esters of thiodiglycol via direct esterification of thiodiglycol with carboxylic acid. The high efficient and reusable catalyst renders the transformation highly valuable from both environmental and economical points of view. This illustrates the potential utility of the methodology for the construction of various long alkyl-chain esters of thiodiglycol.

\section{References}

1. (a) Pollack M A and Penville N J 1948 US patent, 2454568. (b) Boussely J, Chandavoine M, Chignac M et al. 1979 US patent, 4180492 
2. (a) Stegmann W, Meier H R, Evan S et al. 1989 US patent, 4874885. (b) Meier H R and Pitteloud R 1992 US patent, 5167846

3. Clayton W R and Reid E E 1941 J. Am. Chem. Soc. 64 908

4. (a) Otera J 1993 Chem. Rev. 93 1449. (b) Manabe K, Sun $\mathrm{X}$ and Kobayashi S 2001 J. Am. Chem. Soc. 12310101
5. Richter F, Augustine F B, Koft E and Reid E E 1951 J. Am. Chem. Soc. 744076

6. Amos R A, Emblidge R W and Havens N 1983 J. Org Chem. 483598

7. (a) Ishihara K, Ohara S and Yamamoto H 1996 J. Org. Chem. 61 4196. (b) Zhang G S 1999 Synth. Commun. 29 607 